\title{
SEXUAL DIMORPHISM OF THE HYOID BONE. A PRELIMINARY STUDY
}

\author{
BY \\ Seham A. Gad El.Hak; Sahar A. El. Dakroory; \\ Adel A. El.Hawary* and Amr M. Alghazally** \\ Departments of Forensic Medicine and Clinical Toxicology, Anatomy*, Faculty of Medicine, \\ Mansoura University and Port Said Medicolegal Institute**, Ministry of Justice. Egypt.
}

\begin{abstract}
Age and sex-related morphological changes in the human hyoid bone and the presence or absence of bony fusion of greater cornua to the central body were investigated radiographically in a preliminary study on small Egyptian population sample. Thirty-three hyoid bones (22 males and 11 females) from autopsied cases aged from 14-70 years were studied. Seventeen measurements were determined on the radiographs of the bones. Analysis of the results revealed that all the studied hyoid bones are of parabolic type. Some measurements are more sexually dimorphic and have statistical significance differences $(p<0.05)$ than others. e.g. (M3, M4, M6 and M17). Females tend to have smaller hyoid bones in most measurement parameters (M1, M2, M5, M6, M10, M11, M12, M14, M15 and M17) except M7 and M13 are equal in both sexes and M8 and M9 are larger in females. Unilateral and Bilateral osseous fusion are more in males $(12.1 \%, 21.2 \%)$ than females $(3.0 \%, 6.0 \%)$ respectively. These results suggest the possibility of using the hyoid bone in determination of sex of the corpse in cases of analysis of collection of bones.
\end{abstract}

\section{INTRODUCTION}

The hyoid bone is of considerable forensic interest. The bony fusion of its components is of interest to forensic pathologists because of the vulnerability of the hyoid bone to fracture during neck trauma and the significance of such fractures in the diagnosis of cause of death e.g. manual strangulation (O'Halloran and Lundy, 1987).

The shape of hyoid bone may influence its susceptibility to fracture (Pollanen and Ubelaker, 1997) and hyoid fractures are frequently confused with normal variation e.g. incomplete fusion in both clinical (Szeremeta and Morovati, 1991) and forensic settings (Rodriguez, 1986).

The hyoid bone is U-shaped or horse shoe shaped. It lies opposite the upper part of the 4th cervical vertebra and about $2 \mathrm{~cm}$ below the level of the lower margin of the mandible when the head is in the natural position. It may be moved freely 
from side to side and its horse-shoe form is most easily recognized if the two greater horns are held between the index finger and thumb (Simon and Hamilton, 1978).

The hyoid-larynx complex has anatomic interest in the differential diagnosis of traumatic lesions and anatomic anomalies (Nunno, et al., 2004).

The use of radiographic technique for examining hyoid-larynx is a fast, economical method in postmortem examinations (Nunno et al., 1998). The body of the hyoid bone is clearly seen just below the inferior edge of the angle of the mandible. The shadows of both greater and lesser cornua may or may not be superimposed according to the direction of the x-ray beam; they are, however, usually separated from the body of the hyoid by $1 \mathrm{~mm}$. clear space (Simon and Hamilton, 1978).

Conventional x-ray examination is helpful in revealing injuries to hyoid bone and laryngeal cartilages in patients (Dickenson, 1991) or corpses (Lenoir and Mereau, 1985; Lasezkowski and Riepert 1992).

\section{MATERIAL \& METHOD}

Human cadavers were autopsied at Port Said Morgue during the period : July 2004 - December 2004.The hyoid bones (n:33) were obtained from the cadavers whose age ranged between 14 to 70 years.
They were 22 males and 11 females. For analysis, the cases were divided into two age groups: group 1 ; comprised cadavers aged 14-40years and group 2; cadavers aged $>40-70$ years.

The hyoid bones were carefully dissected from the larynx and surrounding connective tissues. Each bone was radiographed with its inferior surface resting directly on the cassette. Care was taken that the optimal distance of focus ensured that each measurement of the bone would correspond accurately with that on the $x$ ray film. Seventeen measurements were taken on each bone plain x-ray, which are illustrated in table I and figure I.

The fusion of greater cornua to the hyoid body was recorded on radiographs as follows: No fusion, unilateral fusion, or bilateral fusion (Figure II). Fusion of the joints of the lesser cornua can not be evaluated on the x-ray radiographs because of difficulties in visualization. It is established that the age of fusion of greater cornu with body of the hyoid bone is 40 years (Simon and Hamilton, 1978).

The statistical analysis of data has done by using excel program and SPSS program (statistical package of social science version 10). The 1st part of the data (Tables 1-5) was descriptive in the form of mean \pm SD because all data are normally distributed (parametric). $2^{\text {nd }}$ part (Table, 6) was 
analytic to test statistical significant difference between groups. Student t-test was used to compare between two groups and one way Anova test for comparing between more than two groups. $\mathrm{P}$ is significant at $\leq 0.05$.

Table (I): Measurements taken on hyoid bones (Miller et al., 1998).

\begin{tabular}{|c|c|}
\hline Measurements & Description \\
\hline $\mathrm{M}_{1}$ & $\begin{array}{l}\text { Distance from mid point of distal end of left greater cornu to the middle of the } \\
\text { joint between left greater cornu and left side of body of hyoid bone. }\end{array}$ \\
\hline $\mathrm{M}_{2}$ & $\begin{array}{l}\text { Distance from midpoint of distal end of right greater cornu to the middle of the } \\
\text { joint between right greater cornu and right side of body of hyoid bone. }\end{array}$ \\
\hline $\mathrm{M}_{3}$ & $\begin{array}{l}\text { Distance between the distal ends of the right and left greater cornua measured } \\
\text { from the center of each bone. }\end{array}$ \\
\hline $\mathrm{M}_{4}$ & $\begin{array}{l}\text { Distance from the middle of left joint space to the middle of the right joint } \\
\text { space, measured across the body of the hyoid in bones exhibiting fusion of one } \\
\text { or both cornua to the hyoid bone, the points of measurement are taken to be the } \\
\text { mid points of the lines of fusion on x-ray. }\end{array}$ \\
\hline $\mathrm{M}_{5}$ & $\begin{array}{l}\text { Perpendicular distance from the midpoint of a line drawn between the distal } \\
\text { ends of the right and left greater cornua to the midpoint of the posterior aspect } \\
\text { of the hyoid body. }\end{array}$ \\
\hline $\mathrm{M}_{6}$ & $\begin{array}{l}\text { Maximum length of the left greater cornu measured between mid point of the } \\
\text { proximal end to midpoint of the distal end. }\end{array}$ \\
\hline $\mathrm{M}_{7}$ & $\begin{array}{l}\text { Maximum width of the distal end of left greater cornu measured perp endicular } \\
\text { to the internal surface of greater cornu. }\end{array}$ \\
\hline $\mathrm{M}_{8}$ & $\begin{array}{l}\text { Minimum width of the distal end of the left greater cornu measured } \\
\text { perpendicular to the internal surface of the greater cornu. }\end{array}$ \\
\hline $\mathrm{M}_{9}$ & $\begin{array}{l}\text { Width of the left greater cornu measured perpen dicular to the internal surface of } \\
\text { the bone at the mid point of the maximum length of left greater cornu. }\end{array}$ \\
\hline $\mathrm{M}_{10}$ & $\begin{array}{l}\text { Maximum width of the proximal end of left greater cornu perpendicular to the } \\
\text { internal surface of the greater cornu. }\end{array}$ \\
\hline $\mathrm{M}_{11}$ & $\begin{array}{l}\text { Maximum length of the right greater cornu measured between mid point of the } \\
\text { proximal end to midpoint of the distal end. }\end{array}$ \\
\hline $\mathrm{M}_{12}$ & $\begin{array}{l}\text { Maximum width of the distal end of the right cornu measured perpendicular to } \\
\text { the internal surface of the greater cornu. }\end{array}$ \\
\hline $\mathrm{M}_{13}$ & $\begin{array}{l}\text { Minimum width of the distal end of the right greater cornu measured } \\
\text { perpendicular to the internal surface of greater cornu }\end{array}$ \\
\hline $\mathrm{M}_{14}$ & $\begin{array}{l}\text { Width of the right greater cornu measured perpendicular to the internal surface } \\
\text { of greater cornu at the mid point of the maximum length of right greater cornu } \\
\text { of the bone. }\end{array}$ \\
\hline $\mathrm{M}_{15}$ & $\begin{array}{l}\text { Maximum width of the proximal end of the right greater cornu measured } \\
\text { perpendicular to the internal surface of the cornu. }\end{array}$ \\
\hline $\mathrm{M}_{16}$ & $\begin{array}{l}\text { Width of the hyoid body at its midpoints measured perpendicular to the internal } \\
\text { surface of the bone. }\end{array}$ \\
\hline $\mathrm{M}_{17}$ & Total length of the hyoid bone ( sum of measurement of $\mathrm{M}_{5}$ and $\mathrm{M}_{16}$ ). \\
\hline
\end{tabular}


Gad El-Hak et al ...
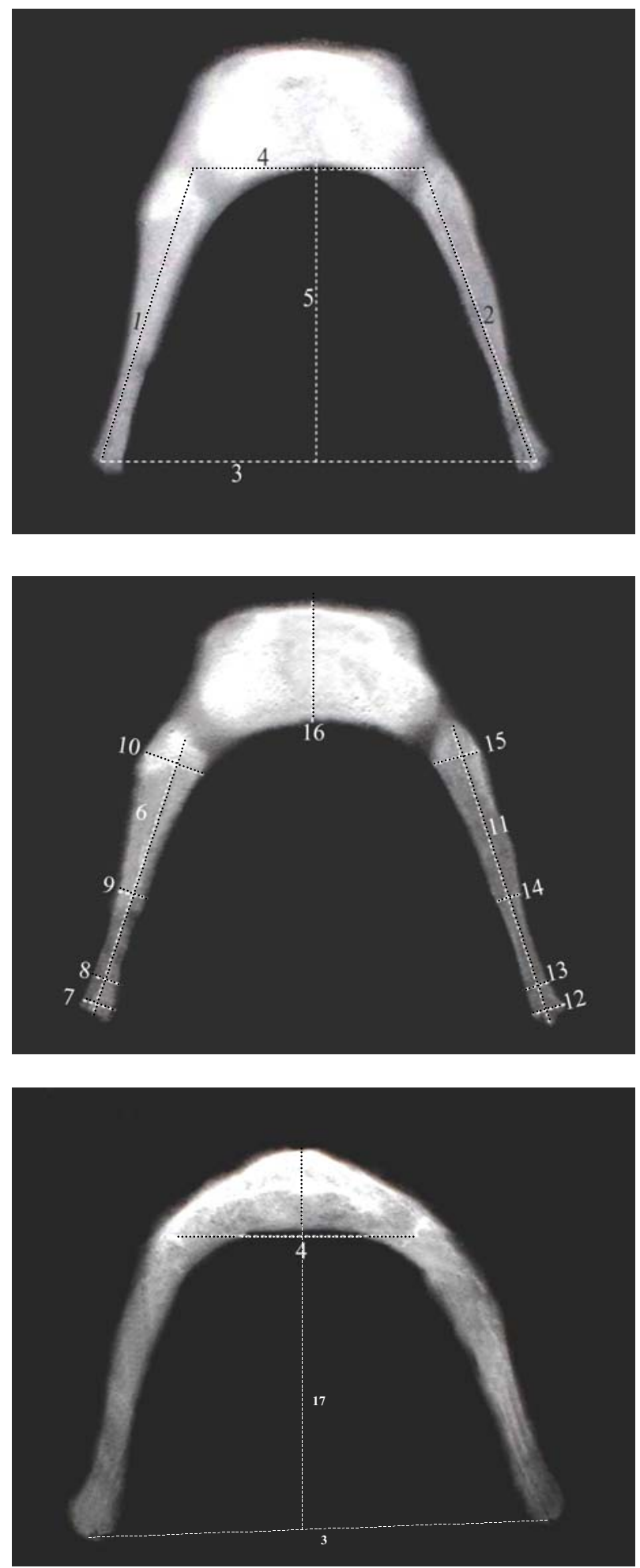

Fig. (I): The seventeen measurements taken on each hyoid bone. 


\section{RESULTS}

Thirty three autopsied hyoid bones were examined. Of these, $22(66.7 \%)$ were males and $11(33.3 \%)$ were females. The cases ranged in age from 14 years to 70 years with mean \pm SD $38.24 \pm$ 17.11. The number of cases in each age group in both sexes are presented in tables $(1,2)$.

Table (3) shows the mean \pm SD of the measurements for each hyoid bone. The data show that width measurement $\left(\mathrm{M}_{3}\right)$ is greater than length measurement $\left(M_{17}\right)$ in both males and females i.e. the studied hyoid bones are of parabolic type which has greater width than length.

There is a wide variation in both sexes in length measurements, $\left(\mathrm{M}_{17}\right)$ ranging from $28 \mathrm{~mm}$. to $43 \mathrm{~mm}$, and width measurements, $\left(\mathrm{M}_{3}\right)$ ranging from $28 \mathrm{~mm}$. to 57 $\mathrm{mm}$. Some measurements are more sexually dimorphic and have statistical significance differences $(p<0.05)$ than others e.g. $\left(M_{3}, M_{4}, M_{6}\right.$ and $\left.M_{17}\right)$. Females tend to have smaller hyoid bones in most measurement parameters $\left(\mathrm{M}_{1}, \mathrm{M}_{2}, \mathrm{M}_{5}, \mathrm{M}_{6}, \mathrm{M}_{10}\right.$, $M_{11}, M_{12}, M_{14}, M_{15}$ and $M_{17}$ ) except $M_{7}$ and $M_{13}$ are equal in both sexes and $M_{8}$ and $\mathrm{M}_{9}$ are larger in females.

Table (4) shows osseous fusion of the greater cornual joints with the body of hyoid bone. Overall, the 33 specimens revealed nineteen cases $(57.5 \%)$ of non fusion of the body with greater cornua [11 males (33.3\%) and eight females $(24.2 \%)]$, five cases $(15.1 \%)$ of unilateral fusion [four males (12.1\%) and one female $(3.0 \%)]$ and nine cases $(27.2 \%)$ of bilateral fusion [seven males $(21.2 \%)$, two females $(6.0 \%)$ ]. Fusion in males began in the fourth decade (unilateral fusion began at 34 years and bilateral fusion began at 40 years) while bilateral fusion began in females in the fifth decade (occurred at 50 years). An unexpected unexplained finding is that one female case aged 63y has bilateral non fusion of the greater cornu to the body and another female aged $65 \mathrm{y}$ has unilateral right nonfusion. The comparison between fusion in both males and females are illustrated in figure (1) as percentages in relation to age decades.

Table (5) illustrates the covariance of hyoid measurements according to sex, age and fusion at autopsy. The results show that the lengths $\left(\mathrm{M}_{6}, \mathrm{M}_{17}\right)$ and widths $\left(\mathrm{M}_{3}\right.$, $\mathrm{M}_{4}$ ) measurements have statistical sexsignificant differences in both sexes $(\mathrm{p}<0.05)$.

According to the age, length measurements $\left(M_{1}, M_{2}, M_{5}, M_{6}, M_{11}\right.$, and $\left.M_{17}\right)$ and width measurements $\left(\mathrm{M}_{4}, \mathrm{M}_{12}\right)$ increase significantly with age $(\mathrm{p}<0.05)$. In general the length measurements have statistical sex and age significant differences; males 
tend to have greater lengths measurements than females.

Regarding fusion, length and width measurements have no statistical significance difference in both sexes.

\section{DISCUSSION}

The hyoid bone is of considerable forensic interest owing to its susceptibility to fracture during strangulation, hanging as well as trauma conditions. The presence of a fractured hyoid bone is often of great importance in cases involving badly decomposed bodies and skeletal remains lacking soft tissue evidence of neck injury (Miller et al., 1998).

The use of radiographs as a means of identification in forensic practice is a well established procedure, performed by radiologists and interpreted by forensic anthropologists or pathologists (Hogge et al., 1994).

Although the relationship between hyoid bone shape and fracture pattern is already existing, there are few data on age and sex differences in hyoid morphology.

This study was done on 33 (22 males, 11 females) Egyptian hyoid bones. It is considered as a preliminary study to evaluate the sexual dimorphism by studying the morphology and fusion of the hyoid bones in both sexes.

The results of the present study show that the hyoid bone shape is related to the parabolic type in both sexes. In contrast, Papadopoulos et al., (1989) found that the common type of hyoid bone shape in women is the hyperbolic type while in men it is parabolic type.

According to age, the results of the present study show that length measurements $\left(M_{1}, M_{2}, M_{5}, M_{6}, M_{11}\right.$, and $\left.M_{17}\right)$ and width measurements $\left(M_{4}, M_{12}\right)$ increase with age with statistical significance $(\mathrm{p}<0.05)$.

In contrast, Papadopoulos et al., (1989) showed that the size and shape of the hyoid bone are highly variable, but no significant relationship has been found with age.

Whereas Shimizu et al. (2005) found morphological changes and sex differences of the hyoid bone with age, and these morphological changes were linked with the fusion between the body and the greater cornu.The authors explained the continuous change of shape by synostosis and the appearance of osteoclasts.The movement in the fused area of junction may induce osteaclasts and bring about the morphological changes. The shape of the hyoid bone may correlate with the 
degree of ossification or fusion. This supports the findings of Miller et al. (1998) who showed that the pattern of hyoid shape variation is continuous with age and fusion rather than bimodal.

As regards to sexual dimorphism, hyoid bone measurements showed that measurements $\left(\mathrm{M}_{3}, \mathrm{M}_{4}, \mathrm{M}_{6}, \mathrm{M}_{17}\right)$ have the greatest sexual dimorphism with statistical significance $(\mathrm{P}<0.05)$. Females tend to have smaller hyoid bones in both dimension parameters with no statistical significance difference in both sexes.

In contrast, Miller et al., (1998) revealed that the distal ends of the greater cornua corresponding to $\left(M_{7}\right.$ and $M_{8}$ in the present study) are more sexually dimorphic than other parts of the bone.

Regarding osseous fusion of the greater cornual joints, data of the present study revealed that fusion began in the $4^{\text {th }}$ decade in males while it occurred in females in the $5^{\text {th }}$ decade. The total percentage of bilateral fusion and unilateral fusion in males $(21.2 \%, 12.1 \%)$ were more than females $(6.0 \%, 3.0 \%)$ respectively. O'Halloran and Lundy (1987) showed that bilateral fusion of the greater cornua to the body was more frequent in men than in women in all age groups after the third decade, and the unilateral fusion was more in women. Discrepancy between the present results and previous studies may be due to the limited number of the present samples which are available during the study period.

An unusual finding is that one female case aged 63y has bilateral non fusion of the greater cornu to the body and another female aged $65 \mathrm{y}$ has unilateral right nonfusion. This is in consistent with Ubelaker, (1992) who found that older females had a lower frequency of fusion compared with older males. Of interest to the forensic pathologist is the frequency of non ossification of the hyoid greater corneal joint in middle and old age. Strangulation should not be ruled unlikely on the basis of a hyoid free of fracture, even in the advanced age, since some of elderly people have persistent and flexible greater corneal joints.

The frequency of unilateral non fusion is of greater importance to the forensic pathologist. Instances have been reported where innocent persons were charged and found guilty of homicidal strangulation in which a major piece of evidence was the mistaken conclusion by the pathologist that the hyoid bone had been fractured (O'Halloran and Lundy, 1987). Side to side differences in the displacement of the bone margin may be related to the unilateral fusion. The fused side may receive dispersed extrinsic force from muscles and ligaments, which displace bone margins (Shimizu et al., 2005). 
The medico-legal importance of the unilateral non-fusion of hyoid bone is the misdiagnosis of it by the pathologist as fracture especially in old age. This aspect which is potentially misleading, as Khokhlov, (1999) has observed, may be correctly interpreted by careful evaluation for the contours of the calcified bone by experienced radiologists.

Ubelaker, (1992) illustrated that the frequency of fusion increases with advancing age, but the body and the greater cornu remain unfused in about $30 \%$ of people older than 40 years. Shimizu et al., (2005) showed that the frequency of fusion and the breadth of the joint space showed no significant increases in older age and the peak of the fusion of the body and the greater cornu occurs at the fifth and sixth decades.

So, careful examination of the hyoid bone grossly and radiologically is very important for the forensic pathologist to distinguish fracture, incomplete fusion, regular articulation between the body and greater horns, and greater horn diastases.

The present study is considered as a preliminary study due to the small number of autopsy cases which were available during the duration of the study. More additional information is needed about the age and sex variation of the lesser cornua because they may be of worthy use in forensic investigations. Further studies on hyoid bones in a large Egyptian population sample would be necessary. 
Table (1): Age and sex of the studied hyoid bones (n .: 33).

\begin{tabular}{|c|c|c|c|c|c|c|c|}
\hline \multirow{2}{*}{$\begin{array}{c}\text { Age } \\
\text { groups }\end{array}$} & \multicolumn{2}{|c|}{ Males } & \multicolumn{2}{|c|}{ Females } & \multicolumn{2}{|c|}{ total } & \multirow{2}{*}{ Chi square test } \\
\hline & n. & $\%$ & n. & $\%$ & n. & $\%$ & \\
\hline $14-40 y$ & 15 & 68.2 & 7 & 31.8 & 22 & 66.7 & \\
\hline$>40-70 y$ & 7 & 63.6 & 4 & 36.4 & 11 & 33.3 & 0.79 \\
\hline Total & 22 & 66.7 & 11 & 33.3 & 33 & 100 & \\
\hline
\end{tabular}

Significant at $p \leq 0.05$.

Table (2): Sex of the studied hyoid bones (n.: 33).

\begin{tabular}{|l|ccc|}
\hline \multicolumn{1}{|c|}{ Sex } & Number & Mean \pm SD & t-test \\
\hline \hline$\bullet$ Male & 22 & $38.818 \pm 15.038$ & \\
$\bullet$ Female & 11 & $37.090 \pm 21.4311$ & 0.789 \\
\hline
\end{tabular}

Table (3): Measurements of the studied hyoid bones (n.: 33) in millimeters.

\begin{tabular}{|c|c|c|c|c|c|c|c|}
\hline \multirow{2}{*}{ Measurements } & \multicolumn{2}{|c|}{ Males } & \multicolumn{2}{|c|}{ Females } & \multicolumn{2}{|c|}{ Means \pm SD } & \multirow[t]{2}{*}{ t-test } \\
\hline & minimum & maximum & minimum & maximum & males & females & \\
\hline $\mathbf{M}_{1}$ & 22 & 38 & 22 & 33 & $29.59 \pm 3.58$ & $27.45 \pm 3.01$ & 0.100 \\
\hline $\mathbf{M}_{2}$ & 20 & 36 & 22 & 33 & $29.63 \pm 3.65$ & $27.63 \pm 2.80$ & 0.122 \\
\hline $\mathbf{M}_{3}$ & 29 & 57 & 28 & 42 & $38.90 \pm 2.72$ & $35.90 \pm 4.25$ & 0.019* \\
\hline $\mathbf{M}_{4}$ & 20 & 29 & 18 & 26 & $23.13 \pm 2.55$ & $20.54 \pm 2.80$ & $0.012 *$ \\
\hline $\mathbf{M}_{5}$ & 16 & 36 & 20 & 34 & $30.04 \pm 4.48$ & $27.09 \pm 3.64$ & 0.068 \\
\hline $\mathbf{M}_{6}$ & 21 & 37 & 21 & 32 & $28.86 \pm 3.60$ & $26.091 \pm 2.98$ & 0.035* \\
\hline $\mathbf{M}_{7}$ & 2 & 4 & 2 & 4 & $3.09 \pm 0.811$ & $3.09 \pm 0.70$ & 1.00 \\
\hline $\mathbf{M}_{8}$ & 1 & 3 & 2 & 3 & $2.13 \pm 0.56$ & $2.27 \pm 0.46$ & 0.493 \\
\hline $\mathbf{M}_{9}$ & 2 & 4 & 2 & 4 & $2.72 \pm 0.70$ & $2.81 \pm 0.60$ & 0.717 \\
\hline $\mathbf{M}_{10}$ & 4 & 7 & 3 & 6 & $4.86 \pm 0.77$ & $4.72 \pm 0.78$ & 0.638 \\
\hline$M_{11}$ & 20 & 35 & 21 & 32 & $29.04 \pm 3.59$ & $26.63 \pm 2.80$ & 0.061 \\
\hline $\mathbf{M}_{12}$ & 2 & 5 & 2 & 4 & $3.36 \pm 0.78$ & $3.09 \pm 0.70$ & 0.340 \\
\hline $\mathbf{M}_{13}$ & 1 & 3 & 2 & 3 & $2.18 \pm 0.50$ & $2.18 \pm 0.40$ & 1.00 \\
\hline $\mathbf{M}_{14}$ & 2 & 5 & 2 & 5 & $2.95 \pm 0.89$ & $2.81 \pm 0.87$ & 0.681 \\
\hline $\mathbf{M}_{15}$ & 4 & 6 & 3 & 6 & $4.95 \pm 0.57$ & $4.81 \pm 0.75$ & 0.566 \\
\hline $\mathbf{M}_{16}$ & 4 & 14 & 5 & 10 & $7.50 \pm 2.15$ & $7.18 \pm 1.6$ & 0.671 \\
\hline $\mathbf{M}_{17}$ & 28 & 43 & 29 & 40 & $37.54 \pm 3.60$ & $34.27 \pm 3.16$ & 0.016* \\
\hline
\end{tabular}

* Significant at $\mathrm{p} \leq 0.05$. 
Table (4) : Frequency of fusion conditions(non fusion, unilateral and bilateral fusion) of the left and right greater cornua to the body of the hyoid bone.

\begin{tabular}{|c|c|c|c|c|c|c|c|c|c|c|c|c|c|}
\hline \multirow{2}{*}{\multicolumn{2}{|c|}{ Age }} & \multicolumn{6}{|c|}{ Fusion in males } & \multicolumn{6}{|c|}{ Fusion in females } \\
\hline & & \multicolumn{2}{|c|}{$\begin{array}{c}\text { non } \\
\text { fusion }\end{array}$} & \multicolumn{2}{|c|}{$\begin{array}{c}\text { unilateral } \\
\text { fusion }\end{array}$} & \multicolumn{2}{|c|}{$\begin{array}{c}\text { bilateral } \\
\text { fusion }\end{array}$} & \multicolumn{2}{|c|}{$\begin{array}{c}\text { non } \\
\text { fusion }\end{array}$} & \multicolumn{2}{|c|}{$\begin{array}{c}\text { unilateral } \\
\text { fusion }\end{array}$} & \multicolumn{2}{|c|}{$\begin{array}{c}\text { bilateral } \\
\text { fusion }\end{array}$} \\
\hline Range & n. & n. & $\%$ & n. & $\%$ & n. & $\%$ & n. & $\%$ & n. & $\%$ & n. & $\%$ \\
\hline $14-40 y$ & 22 & 11 & 50.0 & 3 & 13.6 & 1 & 4.6 & 7 & 31.8 & 0 & 0.0 & 0 & 0.0 \\
\hline$>40-70 y$ & 11 & 0 & 0.0 & 1 & 9.1 & 6 & 54.5 & 1 & 9.1 & 1 & 9.1 & 2 & 18.2 \\
\hline Total & 33 & 11 & 33.3 & 4 & 12.1 & 7 & 21.2 & 8 & 24.2 & 1 & 3.0 & 2 & 6.0 \\
\hline
\end{tabular}

Table (5) : Analysis of covariance of hyoid measurements according to sex, age and fusion at autopsy.

\begin{tabular}{|cc|c|c|c|c|c|}
\hline Hyoid & \multicolumn{2}{c|}{ Sex } & \multicolumn{2}{c|}{ Age } & \multicolumn{2}{c|}{ Fusion } \\
measurements & t-test & $\mathbf{p}$ & $\mathbf{f}^{*}$ & $\mathbf{p}$ & $\mathbf{f}$ & $\mathbf{p}$ \\
\hline Lengths: & & & & & & \\
\hline $\mathbf{M}_{\mathbf{1}}$ & 1.698 & 0.100 & 2.31 & $0.072^{*}$ & 0.591 & 0.560 \\
$\mathbf{M}_{\mathbf{2}}$ & 1.590 & 0.122 & 2.79 & $0.037^{*}$ & 1.189 & 0.318 \\
$\mathbf{M}_{\mathbf{5}}$ & 1.889 & 0.068 & 2.45 & $0.059^{*}$ & 0.823 & 0.449 \\
$\mathbf{M}_{\mathbf{6}}$ & 2.199 & $0.035^{*}$ & 2.99 & $0.028^{*}$ & 0.344 & 0.711 \\
$\mathbf{M}_{\mathbf{1 1}}$ & 1.943 & 0.061 & 3.13 & $0.023^{*}$ & 0.950 & 0.398 \\
$\mathbf{M}_{\mathbf{1 7}}$ & 2.553 & $0.016^{*}$ & 2.68 & $0.043^{*}$ & 0.261 & 0.772 \\
\hline $\mathbf{W i d t h s :}_{\mathbf{1}}$ & & & & & & \\
$\mathbf{M}_{\mathbf{3}}$ & 2.470 & $0.019^{*}$ & 0.61 & 0.691 & 1.265 & 0.297 \\
$\mathbf{M}_{\mathbf{4}}$ & 2.662 & $0.012^{*}$ & 2.32 & $0.070^{*}$ & 3.064 & 0.062 \\
$\mathbf{M}_{\mathbf{7}}$ & 0.000 & 1.00 & 2.30 & 0.072 & 1.646 & 0.210 \\
$\mathbf{M}_{\mathbf{8}}$ & 0.694 & 0.493 & 1.12 & 0.372 & 0.722 & 0.494 \\
$\mathbf{M}_{\mathbf{9}}$ & 0.366 & 0.717 & 0.67 & 0.647 & 1.907 & 0.166 \\
$\mathbf{M}_{\mathbf{1 0}}$ & 0.475 & 0.638 & 0.47 & 0.790 & 2.727 & 0.082 \\
$\mathbf{M}_{\mathbf{1 2}}$ & 0.969 & 0.340 & 3.08 & $0.025^{*}$ & 3.182 & 0.056 \\
$\mathbf{M}_{\mathbf{1 3}}$ & 0.000 & 1.000 & 1.67 & 0.175 & 0.643 & 0.533 \\
$\mathbf{M}_{\mathbf{1 4}}$ & 0.415 & 0.681 & 0.34 & 0.882 & 1.162 & 0.327 \\
$\mathbf{M}_{\mathbf{1 5}}$ & 0.579 & 0.566 & 0.61 & 0.689 & 1.710 & 0.198 \\
$\mathbf{M}_{\mathbf{1 6}}$ & 0.429 & 0.671 & 1.93 & 0.122 & 1.073 & 0.355 \\
\hline
\end{tabular}

- Significant at $\mathrm{p} \leq 0.05$.

- $* \mathrm{f}=$ one way Anova test. 
Gad El-Hak et al ...
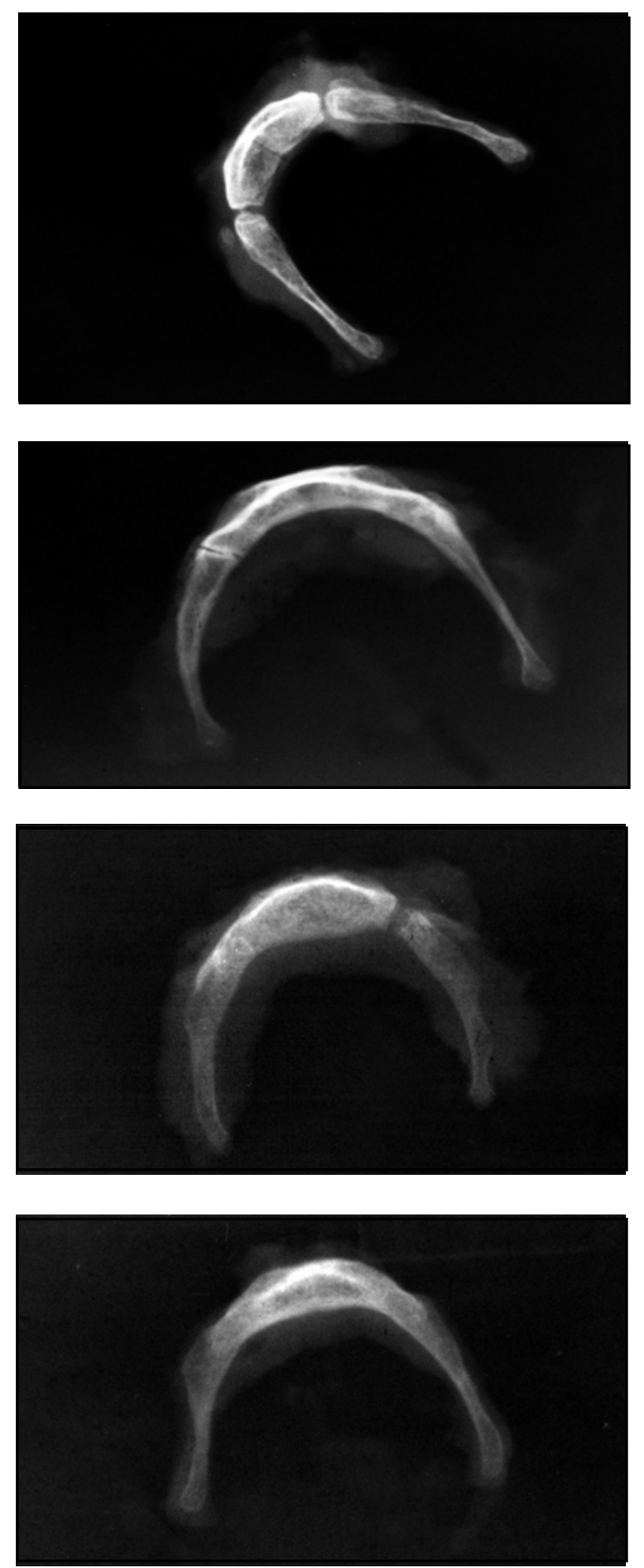

Fig. (II): Radiographic photos showing: a. Non fusion, b. left unilateral fusion, c. right unilateral fusion and d. bilateral fusion in studied hyoid bones. 


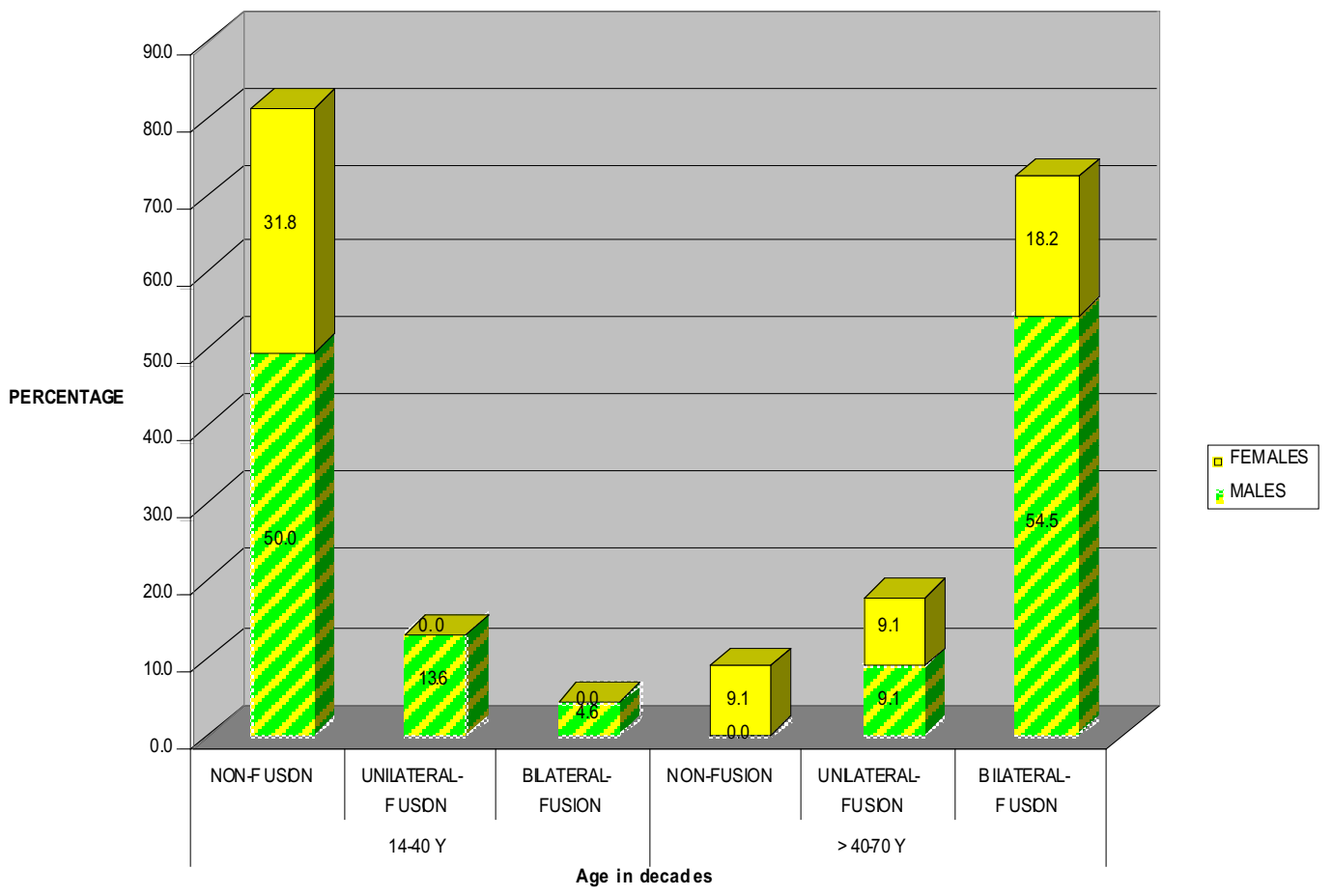

Fig. (1): Frequency of osseous fusion of hyoid bone greater cornua, expressed as a percentage in comparison with age (in decades). Percentages of non fusion, unilateral fusion and bilateral fusion in males and females. 


\section{REFERENCES}

Dickenson, A. J. (1991) : "Fracture of the hyoid bone following minimal trauma." Injury, (5): 420 - 421.

Hogge, J. P.; Messmer, J. M. and Doan, Q. N. (1994) : "Radiographic identification of unknown human remains." J. Forensic. Sci., 39 (2): 373 - 377.

Khokhlov, V. D. (1999) : "Fractures of the laryngopharynx framework as a medico-legal matter." Forensic Sic. Int., 104 : $147-162$.

Lasezkowski, G. and Riepert, C. (1992) : "Zur Problematik des Auffindeortes Badewanne. Klarung eines Todesfalles nach vier Jahren unter Einsatz postmortaller Rontgendiagnostik."(English abstract). Arch. Kriminol., (1-2): 25 - 32.

Lenoir, L. and Mereau, M. (1985) : "Interet de la radiographie systematique $\mathrm{du}$ larynx en medicine legale." J. Med. leg. Droit Med., (3): 191 -195.

Miller, K. W. P.; Walker, P. L. and O'Halloran R. 1. (1998) : "Age and sex - related variation in hyoid bone morphology." J. Forensic Sci., 43 (6): 1138 - 1143.

Nunno, Di N.; Lombardo, S.; Costantinides, F. and Cosimo, Di N. (2004) : "Anomalies and alterations of the hyoid - larynx complex in forensic radiographic studies." Am. J. Forensic Med. Pathol., 25: $14-19$.

Nunno, Di N.; Costantinides, F. and Bernasconi, P. (1998) : "Radiographic magnification in the diagnosis of traumatic lesions of the hyoid - larynx complex." Int. J. legal Med., 111: 38 - 42.

O'Halloran, R. L. and Lundy, J. K. (1987) : "Age and ossification of the hyoid bone: forensic implications." J. Forensic Sci., 32 (6): 1655 -1659.

Papadopoulos, N., Lykaki Anastopoulou, G. and Alvanidou, E. 1. (1989) : "The shape and size of the human hyoid bone and a proposal for an alternative classification" J. Anat., 163: 249 - 260.

Pollanen, M. S. and Ubelaker, D. H. (1997): "Forensic significance of the polymorphism of hyoid bone shape." J. Forensic Sci., 42 (5): 890 -892.

Rodriguez, W. C. (1986) : "Morphological variation and fracture patterns in the hyoid bone." Am. Acad. Forensic Sci., (Annual Meeting): 10 - 15.

Shimizu, Y.; Kanetaka, H.; Kim, Y. H., Okayama, K; Kano, M. and Kikuchi, M. (2005) : "Age-related morphological changes in the human hyoid bone." Cells Tissues Organs, 180 : 185 - 192. 
Simon, G. and Hamilton, W. J. (1978) : (1991) : "Isolated hyoid bone fracture: A The head and the neck. In : X-Ray Anato- case report and review of the literature." J. my. Butterworths \& Co ltd, London, P.P. Trauma, (31): 268-271. $273-327$.

Ubelaker, D. H. (1992) : "Hyoid fracture

Szeremeta, W. and Morovati, S. S. and strangulation". J. Forensic Sci., 35 (5):1216-1222. 


\title{
الإذوواج الشكلى الجنسى فى العظمة اللا مية دراسة عبدئية
}

\author{
المشتركون فى البحث \\ د. سحر عبدالعزيز الدكرورى العز

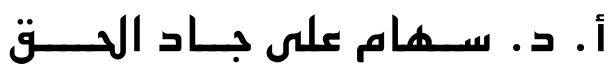

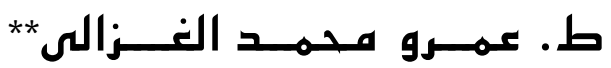

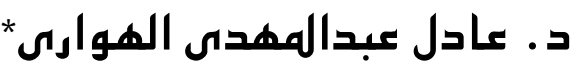 \\ قسم الطب الشرعى والسموم الإكلينيكية، قسم التشريح* - كلية الطب - جامعة المنصورة
}

أجرى البحث على عدد بr من العظم اللامى من حالات تشريحية للمتوفيين فى مصلحة الطب الشرعى ببورسعيد فى الفترة من يوليو

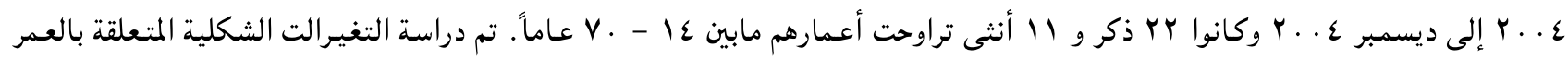

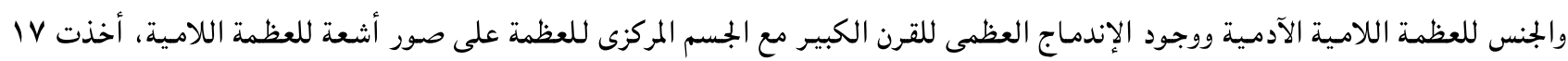
قياسات على صور الأشعة وتم دراسة الأطوال، القياسات العرضية والاندماج العظمى. أظهرت النتائج أن العظم اللامى لكل من الذكور والإناث

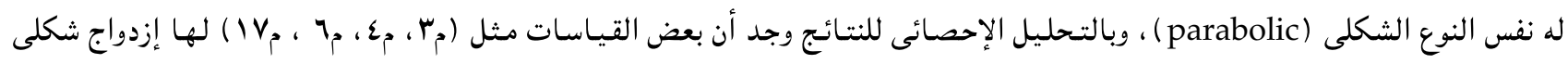

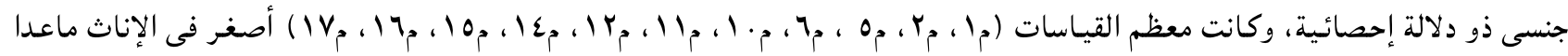

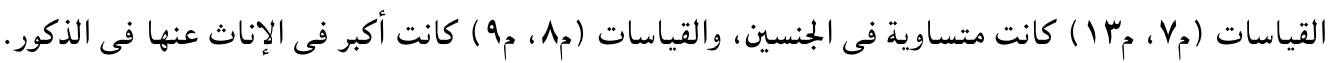

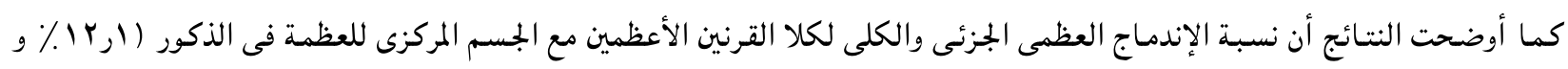

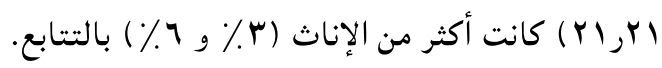
وقد أثبتت الدراسة الإحصائية أهمية إستخدام قياسات العظم اللامى فى تحديد نوع الجنس بعد الوفاة، ويوصى الباحثون إجراء المزيد من الدراسات على أعداد أكبر من العظام اللامية للجنسين حتى تعطى نتائج أكثر دقة وحساسية ليمكن إستخدامها فى بنوك المعلومات الخاصة بعظام المصريين. 